\title{
Advances in understanding Pseudomonas
}

\section{Burkhard Tümmler*, Lutz Wiehlmann, Jens Klockgether and Nina Cramer}

Address: Klinische Forschergruppe, Klinik für Pädiatrische Pneumologie, Allergologie und Neonatologie, OE 6710, Medizinische Hochschule Hannover, Carl-Neuberg-Str. 1, D-30625 Hannover, Germany

*Corresponding author: Burkhard Tümmler (tuemmler.burkhard@mh-hannover.de)

FI000Prime Reports 2014, 6:9 (doi:10.12703/P6-9)

This is an open-access article distributed under the terms of the Creative Commons Attribution-Non Commercial License (http://creativecommons.org/licenses/by-nc/3.0/legalcode), which permits unrestricted use, distribution, and reproduction in any medium, provided the original work is properly cited. You may not use this work for commercial purposes.

The electronic version of this article is the complete one and can be found at: http://f1000.com/prime/reports/b/6/9

\begin{abstract}
Pseudomonas aeruginosa, the type species of pseudomonads, is an opportunistic pathogen that colonizes a wide range of niches. Current genome sequencing projects are producing previously inconceivable detail about the population biology and evolution of $P$. aeruginosa. Its pan-genome has a larger genetic repertoire than the human genome, which explains the broad metabolic capabilities of $P$. aeruginosa and its ubiquitous distribution in aquatic habitats. P. aeruginosa may persist in the airways of individuals with cystic fibrosis for decades. The ongoing whole-genome analyses of serial isolates from cystic fibrosis patients provide the so far singular opportunity to monitor the microevolution of a bacterial pathogen during chronic infection over thousands of generations. Although the evolution in cystic fibrosis lungs is neutral overall, some pathoadaptive mutations are selected during the withinhost evolutionary process. Even a single mutation may be sufficient to generate novel complex traits provided that predisposing mutational events have previously occurred in the clonal lineage.
\end{abstract}

\section{Advances in understanding Pseudomonas by genomics}

Pseudomonads are renowned for their metabolic versatility and widespread spatiotemporal distribution [1]. The type species Pseudomonas aeruginosa has become a major opportunistic pathogen for humans and this is probably the underlying incentive for most research that is currently performed on $P$. aeruginosa. Hence if we want to talk about advances in understanding Pseudomonas we can confine ourselves to $P$. aeruginosa. Thanks to the revolution of next generation sequencing, most new knowledge - at least in quantitative terms - has been generated during the last few months and years in Pseudomonas genomics. We are now starting to understand the evolution and population biology of $P$. aeruginosa and its interaction with the environment at the whole genome scale, which can provide us with some general insight into the diversity, ecology and evolution of the microbial world.

\section{Population genomics}

$P$. aeruginosa is a fascinating ubiquitous microorganism that can thrive at low densities within the range of
$4{ }^{\circ} \mathrm{C}$ to $42^{\circ} \mathrm{C}$ in inanimate aquatic habitats and can colonize the surface of animate hosts ranging from worms and flies to plants and mammals [1].

The $P$. aeruginosa population has an epidemic structure [2]. With the exception of a genomic region around the origin of replication, DNA segments can freely recombine between clonal complexes, although the individual clonal frames remain remarkably stable over time (our own unpublished genome sequencing data). By genotyping a large collection of strains from environmental and disease habitats with a custom-made multi-marker array [3] we have identified more than a thousand different clonal complexes, the majority of which are rare [3-4]. Just 20 clones make up about $40 \%$ of the contemporary population. Members of the two major clones C [5] and PA14 [6] were sampled from salt and fresh water, secluded national reserves, anthropogenically polluted sites, plants, wild and domestic animals and acute and chronic human infections. In other words, these two global clones are everywhere. However, the 20 next frequent clones predominate in particular 
geographic areas and/or habitats. Numerous clones still have no representative among the subset of human infections and, conversely, clones that had previously caused outbreaks of nosocomial infection still lack an environmental isolate in our strain collection. These data suggest that the $P$. aeruginosa population consists of global and local generalists on the one hand and niche specialists on the other.

To verify this statement, genome data mining may provide the first evidence. During the last decade most information about the genetic repertoire of $P$. aeruginos $a$ has been gathered from the genomes of the reference strains PAO1 [7] and PA14 [8]. Matching phenotypes were seen for orthologs of metabolic enzymes, whereas complex phenotypes (such as virulence traits) were combinatorial in nature, that is, the encoded function of a gene was modified by epistatic interactions [8]. Even a rather simple trait such as colony morphology was induced by mutagenesis of a peculiar gene in one strain, but not in another [9]. These pilot studies provide evidence that phenotypic diversity in the $P$. aeruginosa population cannot solely be ascribed to sequence variation and/or the presence or absence of genes, but rather results from an interplay between trait-shaping key genes, genetic modifiers and clonal genomic background. However, prior to addressing this complex issue, we need an inventory of genes and sequence variants to describe the genomic diversity of $P$. aeruginosa.

Ongoing genome sequencing projects in our own and other laboratories indicate that the core genome common to all $P$. aeruginosa consists of somewhat more than 4,000 genes. The so-called regions of genome plasticity $[10,11]$ make up the variable accessory genome of about a further 10,000 genes. Variable subsets of this accessory gene pool are present in individual strains and clonal complexes [11]. On top of that, between dozens and hundreds of unique genes previously unknown in $P$. aeruginosa have regularly been observed whenever a strain of a yet uncharacterized clonal complex was subjected to genome sequencing [12-16]. Since more than 1,000 clonal complexes have already been identified in $P$. aeruginosa, we can estimate a pool of 100,000 further "private" genes that are rare or very rare in the $P$. aeruginosa population. The publication of the P. aeruginosa PAO1 genome sequence in the year 2000 [7] classified 2,500 PAO1 open reading frames as hypotheticals of unknown function. Since then, 300 of this number have been functionally characterized by the Pseudomonas community [17], so one can imagine the challenge remaining to achieve a comprehensive insight into the encoded genetic repertoire of the $P$. aeruginosa pan-genome.
Another subset of genes that had been underappreciated prior to the advent of RNA-sequencing are small regulatory RNAs (sRNAs) that, for example, shape the adaptive response to environmental cues by titrating regulatory proteins or base-pairing with target mRNAs [18]. RNA-sequencing of PAO1 [19] or PA14 [20] bacteria grown in planktonic culture in Luria-Bertani (LB) broth has already identified over 500 novel small RNAs or cis-antisense RNAs in addition to the previously known 44 sRNAs. Further sRNAs will probably show up under other experimental conditions and in other clonal complexes, because non-coding RNAs are preferentially localized in the accessory genome [20].

The closest homologs of genes of the accessory genome are typically found in $\beta$ - and $\gamma$-proteobacteria, mostly in other pseudomonads, enterobacteriaceae, and species of the genera Burkholderia $[21,22]$, Ralstonia [23] and Cupriavidus [24] that had been classified as pseudomonads prior to the introduction of 16S rDNA sequencebased molecular taxonomy [25]. Burkholderia, Ralstonia and Cupriavidus bacteria are still called honorary pseudomonads because, like the true pseudomonads, they are metabolically versatile and can utilize a broad range of compounds as carbon and nitrogen sources and even degrade halogenated xenobiotics. The operons that encode these extraordinary metabolic capabilities are typically located in genomic islands, which are shuffled across genus and species barriers by horizontal gene transfer $[26,27]$. An intriguing example is a PAGI-2 island that was detected with $100 \%$ sequence identity in a Cupriavidus metallidurans isolate from heavy-metal ion polluted soil and some 1,000 miles apart in a $P$. aeruginosa isolate from the chronically infected airways of a patient with cystic fibrosis [28]. In other words, the GC-rich $P$. aeruginosa apparently exchanges its gene pool of the accessory genome with other GC-rich proteobacteria that enjoy a similar lifestyle and metabolic versatility.

The intraspecies transfer of genomic islands among $P$. aeruginosa strains has been determined to occur at a frequency of $10^{-6}$ to $10^{-2}$ [28-30], meaning that only a minority of cells within the $P$. aeruginosa community is capable of horizontal transfer of the island [31]. The activation occurs at random and is associated with a loss of fitness to grow, which apparently restricts the number of transfer-competent donors to a few cells.

Genome mobility in P. aeruginosa is typically accomplished by horizontal gene transfer of plasmids, transposons, genomic islands and bacteriophages. Recent work has made $P$. aeruginosa into a model organism for the study of bacterial genome integrity in the context of 
the co-evolution of phage and bacteria [32,33]. Bacterial CRISPR/Cas systems mediate phage resistance. These systems consist of clustered regularly interspaced short palindromic repeats (CRISPR) coupled with cas (CRISPR-associated) genes. Similar to RNA interference in eukaryotes, these CRISPR/Cas systems use small RNAs for sequence-specific detection and neutralization of invading genomes. In $P$. aeruginosa PA14, the type I-F CRISPR/Cas system was shown to prevent the replication of phages [32] and, conversely, the genomes of phages infecting strain PA14 harbour the first known "antiCRISPR" genes that mediate the inhibition of a CRISPR/ Cas system [33].

\section{Genome evolution in chronic cystic fibrosis lung infection}

$P$. aeruginosa causes a wide range of infections in humans that can vary from local to systemic, subacute to chronic, and superficial and self-limiting to life-threatening [1]. Chronic airway infections with $P$. aeruginosa are regularly seen in patients with advanced stages of chronic obstructive pulmonary disease [34,35] and individuals suffering from the autosomal recessive trait cystic fibrosis [36]. The basic defect of a perturbed ion, water and $\mathrm{pH}$ homeostasis predisposes the cystic fibrosis airways to colonization with opportunistic pathogens [37], predominantly Staphylococcus aureus and P. aeruginosa. Once $P$. aeruginosa has taken up residence in the cystic fibrosis lungs for more than a year, the organism is notoriously resistant to eradication by chemotherapy. Unless the patients become co-infected by a transmissible strain, more than $50 \%$ of patients will still be harbouring the initially acquired clone after 20 years of colonization [38]. The chronic infections of the stomach with Helicobacter pylori [39] and of the cystic fibrosis airways with $P$. aeruginosa [38] are the only cases of infections with extracellular bacteria in humans where the causative agent persists in its niche for decades and does not disseminate into other organs. These two scenarios provide a unique opportunity to monitor the genome evolution of a human pathogen in a disease habitat over many years.

Maynard Olson's group has investigated the genetic adaptation of $P$. aeruginosa to cystic fibrosis airways in the single child of a cystic fibrosis newborn cohort who became chronically colonized with $P$. aeruginosa during infancy [40]. Numerous loci were hit by mutation in the child's serial airway isolates collected over an 8-year observation period. Of these, the gene loci encoding multidrug efflux pumps and regulators of quorum sensing and alginate biosynthesis were subsequently confirmed by genotyping of a large strain collection to be hot-spots of mutation of $P$. aeruginosa isolates in cystic fibrosis lungs [40].
The cystic fibrosis clinics in Copenhagen and Hanover have regularly collected $P$. aeruginos $a$ from the airways of all their patients who became chronically colonized in the 1970s and 1980s [38,41]. The analysis of these unique strain collections taken from numerous patients should provide a more comprehensive insight into the microevolution of $P$. aeruginosa during the chronic infection of cystic fibrosis airways than the single case of the infant from the US and hence whole genome sequencing of serial isolates has been performed at both sites.

The molecular epidemiology was different at the two clinics. Patients from the Hanover clinic became colonized with clones that are found at a similar frequency in the environment and other cystic fibrosis clinics [38]. In contrast, the Copenhagen patient cohort became chronically colonized with two highly related clones (DK1 and DK2) by patient-to-patient spread $[38,41]$.

At the Hanover clinic, no turnover of clones was caused by nosocomial acquisition from other patients. Hence the microevolution of the initially acquired clone in patients' airways could be followed over 30 years (currently ongoing). We started with the investigation of microevolution of the globally most abundant clones $\mathrm{C}$ and PA14 in two cystic fibrosis patients' airways [42]. Both clones underwent phenotypic conversion that is typical for the cystic fibrosis lung habitat [43], that is, they became less motile, secreted less siderophores and virulence effectors and became deficient in the lipopolysaccharide (LPS) O-antigen, but they remained non-mucoid [42]. Late isolates were only slightly compromised in competitive growth in the presence of first isolates which, did not confirm the common belief in the literature that adaptation in the cystic fibrosis lungs is accompanied by a loss of global fitness of $P$. aeruginosa. For clone $\mathrm{C}$, a loss-of-function mutation in the DNA repair gene mutL generated a bushy structure of multiple hypermutable clades [44-46] that accumulated close to 1,000 de novo mutations, but interestingly the mutation rate returned to normal in the mutL-deficient lineages after 10 years of colonization. No hypermutators arose in the PA14 lineage. The initial PA14 clade diverged into three clades during the first years of colonization, but after 15 years only one clade persisted in the cystic fibrosis lungs indicating that only this clade was endowed with the features to cope with the on-going remodelling and dedifferentiation of the chronically inflamed airways.

We are currently investigating the genome evolution of $P$. aeruginosa in contrasting patient cohorts with a very mild or very severe course of their infection (our own unpublished data). Exopolysaccharide biosynthesis, 
antimicrobial resistance and global regulators of lifestyle and metabolism were found to be common functional categories whose genes were hit by mutations in all $P$. aeruginosa clones, irrespective of the severity of infection in the cystic fibrosis host. Microevolution, however, was not uniform in the patients' lungs. For example, the $P$. aeruginosa clone inhabiting the most severely affected lungs generated progeny with stop mutations or drastic amino acid changes in key genes of lifestyle, whereas the $P$. aeruginosa clone that has persisted in a patient with normal lung function had diverged into co-existing clades which, accumulated benign, probably modifying amino acid substitutions, but no stop mutations.

These two cases demonstrate that the acquisition of a few mutations can make a major impact on bacterial phenotype. The fact that a single loss-of-function mutation can have dramatic consequences is also the "take home lesson" of intraclonal genome comparisons [47]. Clones CHA and TB were chosen for analysis because the clone members CHA and TBCF10839 confer unusual and severe traits of virulence. Both strains undermine man's major host defence against $P$. aeruginosa, that is, killing by macrophages or neutrophils. By virtue of its type III secretion system, strain CHA destroys host defence cells by a mechanism called "pack swarming" whereby dozens of bacteria simultaneously attack and destroy the mammalian cell [48]. For genome comparison, a clone CHA isolate from the river Ruhr and the first $P$. aeruginosa isolate from a cystic fibrosis patient from another clinic were chosen [47]. These two other strains are not capable of pack swarming. The genomes of the three strains were more than $99.9 \%$ identical. Each strain was carrying a few specific elements in its accessory genome and some dozen strain-specific single nucleotide polymorphisms (SNPs) reflecting the diverse spatiotemporal origin of the strains. However, the exceptional pathogenicity of strain CHA was attributed to a combined deletion of the lactate dehydrogenase and gacS genes, the latter being the major switch between the sessile biofilm-forming and the planktonic exoproteinsecreting lifestyles. Disruption of gacS created a strain that is both mucoid and proficient in the secretion of virulence effectors.

The second example of clone TB is equally illuminating [49]. The two cystic fibrosis strains TBCF121838 and TBCF10839 just differed in one gene deletion, less than 10 SNPs and one insertion of a genomic island from each other, but their phenotype was dramatically different in transcriptome, proteome, metabolome and adherence [46]. TBCF121838 was efficiently killed by neutrophils, whereas TBCF10839 could grow and multiply in polymorphonuclear cells (PMNs). The atypical virulence of strain TBCF10839 was caused by the pleiotropic consequences of a deletion within the pilQ gene that is essential for pilus biogenesis. The other pilins were still synthesized [50], secreted by alternative routes and facilitated the intracellular survival of TBCF10839 in PMNs. In conclusion, microevolution in $P$. aeruginosa can generate novel complex traits by a few or even single mutations, provided that predisposing mutational events had occurred before in the clonal lineage [49].

Complementary to our study on the genome evolution of distinct clones in a cohort of patients seen at the Hanover clinic, a retrospective study has been performed on the genome evolution of the transmissible DK2 clone in a cohort of patients seen at the Copenhagen cystic fibrosis clinic [51-54]. Genome sequencing of 55 bacterial isolates collected from 21 cystic fibrosis patients over 38 years uncovered 8,530 mutations [54]. Overall, no evidence was found for either intragenic bias of mutations or for positive selection within coding regions. The 65 most frequently mutated genes, however, showed clear signs of positive selection. A large part of these genes should be involved in niche adaptation because they are associated with the composition of the cell envelope, antibiotic resistance and evasion of the host response.

Besides these investigations on the DK1 and DK2 clones from Denmark, genomic and phenotypic analyses are being pursued on further transmissible $P$. aeruginosa strains that have caused patient-to-patient spread in cystic fibrosis clinics, namely in Australia, Canada and the United Kingdom [55-64]. A consortium from these three countries headed by Fiona Brinkman (Vancouver), Roger Levesque (Quebec City) and Craig Winstanley (Liverpool) will sequence a further $1000 \mathrm{P}$. aeruginosa genomes in the context of cystic fibrosis lung infections. It is anticipated that we will be able to link the data to the Pseudomonas.com website, integrate the information with patient data registries in cystic fibrosis and develop a user-friendly pipeline for researchers and clinicians.

\section{Further current topics of Pseudomonas research}

This report focuses on our progress in understanding Pseudomonas in the context of genomics and its application to evolution, epidemiology and clinical microbiology. Besides these global genome-wide approaches, more thematically-oriented research is prospering in the 
Pseudomonas field. Several major topics of interest were discussed at the Pseudomonas 2013 conference:

(a) the world of non-coding RNAs $[18,65,66]$;

(b) the dissection of sigma factor regulons [67];

(c) structure and function of the type II, type III and type VI secretion systems (T6SSs) [68-80];

(d) the physiological functions of secondary metabolites such as phenazines [81-85];

(e) quorum sensing inhibitors [86,87];

(f) the sessile biofilm-forming lifestyle [88-94];

(g) and the interaction of $P$. aeruginosa with its competitors in the microbial community $[73,77,78,82-85,95]$.

Of these topics, the ongoing progress in the understanding of the T6SS [96] is particularly impressive. T6SSs are molecular nanomachines allowing Gram-negative bacteria to transport and inject proteins into a wide variety of target cells $[76,78]$. The T6SS is composed of 13 core components and displays structural similarities with the tail-tube of bacteriophages [76,97]. The phage uses a tube and a puncturing device to penetrate the cell envelope of target bacteria and inject DNA. T6SS is considered to be an inverted bacteriophage device creating a specific path in the bacterial cell envelope to drive effectors and toxins to the surface [76]. The P. aeruginosa PAO1 genome encodes three T6SSs, namely H1-, H2-, and H3-T6SS.

P. aeruginosa H1-T6SS targets at least three effector proteins (Tse1-3) to recipient Gram-negative cells $[73,74,98]$. The Tse2 protein is a cytoplasmic effector that induces the quiescence of target cell proliferation, thus providing a pronounced fitness advantage for $P$. aeruginosa donor cells [74]. The amidase Tse 1 and the muramidase Tse 3 are injected into the periplasm of target bacteria in a cell contact-dependent manner and degrade the peptidoglycan leading to the death of the recipients [73]. To protect itself from the action of the Tse toxins, $P$. aeruginosa uses specific periplasmically localized immunity proteins $[73,74]$.

The role of H3-T6SS is still unknown, but the function and regulation of H2-T6SS are starting to be elucidated [77]. H2-T6SS secretes a phospholipase D that releases choline from phosphatidylcholine and thereby leads to a severely perturbed membrane phospholipid composition in the recipient cell. Thus the H2-T6SS delivers an enzyme that is active against both prokaryotic [77] and eukaryotic membranes [75,99]. This strategy of membrane targeting may contribute to the fitness of $P$. aeruginosa in interspecies competition under T6Sconducive conditions [77].

\section{Abbreviations}

Cas, CRISPR-associated; CRISPR, clustered regularly interspaced short palindromic repeat; LB, Luria-Bertani; LPS, lipopolysaccharide; PMNs, polymorphonuclear cells; SNPs, single nucleotide polymorphisms; sRNA, small regulatory RNA; T6SS, type VI secretion system.

\section{Disclosures}

The authors declare that they have no disclosures.

\section{Acknowledgments}

Work in the authors' laboratory is supported by the Deutsche Forschungsgemeinschaft (SFB 900, project A2), the Bundesministerium für Bildung und Forschung (Medizinische Infektionsgenomik, Az 0315827A) and the Christiane Herzog Stiftung.

\section{References}

I. Ramos J: Pseudomonas. New York: Kluwer Academic/Plenum Publishers; 2004.

2. Pirnay J, Bilocq F, Pot B, Cornelis P, Zizi M, van Eldere J, Deschaght P, Vaneechoutte M, Jennes S, Pitt T, de Vos D: Pseudomonas aeruginosa population structure revisited. PLoS ONE 2009, 4:e7740.

3. Wiehlmann L, Wagner G, Cramer N, Siebert B, Gudowius P, Morales G, Köhler T, van Delden C, Weinel C, Slickers P, Tümmler B: Population structure of Pseudomonas aeruginosa. Proc Natl Acad Sci USA 2007, 104:8101-6.

FlOOOPrime RECOMMENDED

4. Selezska K, Kazmierczak M, Müsken M, Garbe J, Schobert M, Häussler S, Wiehlmann L, Rohde C, Sikorski J: Pseudomonas aeruginosa population structure revisited under environmental focus: impact of water quality and phage pressure. Environ Microbiol 2012, 14:1952-67.

5. Römling U, Kader A, Sriramulu DD, Simm R, Kronvall G: Worldwide distribution of Pseudomonas aeruginosa clone $\mathbf{C}$ strains in the aquatic environment and cystic fibrosis patients. Environ Microbiol 2005, 7:1029-38.

6. Rahme LG, Stevens EJ, Wolfort SF, Shao J, Tompkins RG, Ausubel FM: Common virulence factors for bacterial pathogenicity in plants and animals. Science 1995, 268:1899-902.

7. Stover CK, Pham XQ, Erwin AL, Mizoguchi SD, Warrener P, Hickey MJ, Brinkman FS, Hufnagle WO, Kowalik DJ, Lagrou M, Garber RL, Goltry L, Tolentino E, Westbrock-Wadman S, Yuan Y, Brody LL, Coulter SN, Folger KR, Kas A, Larbig K, Lim R, Smith K, Spencer D, Wong GK, Wu Z, Paulsen IT, Reizer J, Saier MH, Hancock RE, Lory S, et al.: Complete genome sequence of Pseudomonas aeruginosa PAOI, an opportunistic pathogen. Nature 2000, 406:959-64.

8. Lee DG, Urbach JM, Wu G, Liberati NT, Feinbaum RL, Miyata S, Diggins LT, He J, Saucier M, Déziel E, Friedman L, Li L, Grills G, Montgomery K, Kucherlapati R, Rahme LG, Ausubel FM: Genomic 
analysis reveals that Pseudomonas aeruginosa virulence is combinatorial. Genome Biol 2006, 7:R90.

\section{FIOOOPrime}

9. Rakhimova E, Munder A, Wiehlmann L, Bredenbruch F, Tümmler B: Fitness of isogenic colony morphology variants of Pseudomonas aeruginosa in murine airway infection. PLOS ONE 2008, 3:el685.

10. Mathee K, Narasimhan G, Valdes C, Qiu X, Matewish JM, Koehrsen M, Rokas A, Yandava CN, Engels R, Zeng E, Olavarietta R, Doud $M$, Smith RS, Montgomery P, White JR, Godfrey PA, Kodira C, Birren B, Galagan JE, Lory S: Dynamics of Pseudomonas aeruginosa genome evolution. Proc Natl Acad Sci USA 2008, I05:3100-5.

\section{FlOOOPrime \\ RECOMMENDED}

II. Klockgether J, Cramer N, Wiehlmann L, Davenport CF, Tümmler B: Pseudomonas aeruginosa Genomic Structure and Diversity. Front Microbiol 201 I, 2:150.

12. Winstanley C, Langille MGI, Fothergill JL, Kukavica-Ibrulj I, ParadisBleau C, Sanschagrin F, Thomson NR, Winsor GL, Quail MA, Lennard N, Bignell A, Clarke L, Seeger K, Saunders D, Harris D, Parkhill J, Hancock REW, Brinkman FSL, Levesque RC: Newly introduced genomic prophage islands are critical determinants of in vivo competitiveness in the Liverpool Epidemic Strain of Pseudomonas aeruginosa. Genome Res 2009, I9:12-23.

13. Roy PH, Tetu SG, Larouche A, Elbourne L, Tremblay S, Ren Q, Dodson R, Harkins D, Shay R, Watkins K, Mahamoud Y, Paulsen IT: Complete genome sequence of the multiresistant taxonomic outlier Pseudomonas aeruginosa PA7. PLoS ONE 2010, 5:e8842.

14. Stewart RMK, Wiehlmann L, Ashelford KE, Preston S], Frimmersdorf E, Campbell BJ, Neal TJ, Hall N, Tuft S, Kaye SB, Winstanley C: Genetic characterization indicates that a specific subpopulation of Pseudomonas aeruginosa is associated with keratitis infections. J Clin Microbiol 201 I, 49:993-I003.

I5. Wu D, Ye J, Ou H, Wei X, Huang X, He Y, Xu Y: Genomic analysis and temperature-dependent transcriptome profiles of the rhizosphere originating strain Pseudomonas aeruginosa MI8. BMC Genomics 201 I, 12:438.

16. Jeukens J, Boyle B, Bianconi I, Kukavica-Ibrulj I, Tümmler B, Bragonzi A, Levesque RC: Complete Genome Sequence of Persistent Cystic Fibrosis Isolate Pseudomonas aeruginosa Strain RP73. Genome Announc 2013, I.

17. Winsor GL, Lam DKW, Fleming L, Lo R, Whiteside MD, Yu NY, Hancock REW, Brinkman FSL: Pseudomonas Genome Database: improved comparative analysis and population genomics capability for Pseudomonas genomes. Nucleic Acids Res 20 I I, 39: D596-600.

\section{FlOOOPrime}

18. Sonnleitner E, Romeo A, Bläsi U: Small regulatory RNAs in Pseudomonas aeruginosa. RNA Biol 20I2, 9:364-7I.

19. Gómez-Lozano M, Marvig RL, Molin S, Long KS: Genome-wide identification of novel small RNAs in Pseudomonas aeruginosa. Environ Microbiol 2012, I4:2006-16.

\section{FlOOOPrime} RECOMMENDED

20. Wurtzel O, Yoder-Himes DR, Han K, Dandekar AA, Edelheit S, Greenberg EP, Sorek R, Lory S: The single-nucleotide resolution transcriptome of Pseudomonas aeruginosa grown in body temperature. PLoS Pathog 2012, 8:e 002945.

\section{FlOOOPrime}

\section{RECOMMENDED}

21. Compant S, Nowak J, Coenye T, Clément C, Ait Barka E: Diversity and occurrence of Burkholderia spp. in the natural environment. FEMS Microbiol Rev 2008, 32:607-26.

22. Vandamme $P$, Dawyndt $P$ : Classification and identification of the Burkholderia cepacia complex: Past, present and future. Syst Appl Microbiol 201 I, 34:87-95.
23. Remenant B, Coupat-Goutaland B, Guidot A, Cellier G, Wicker E, Allen C, Fegan M, Pruvost O, Elbaz M, Calteau A, Salvignol G, Mornico D, Mangenot S, Barbe V, Médigue C, Prior P: Genomes of three tomato pathogens within the Ralstonia solanacearum species complex reveal significant evolutionary divergence. BMC Genomics 2010, I I:379.

24. Rozycki $\mathrm{T}$ von, Nies $\mathrm{DH}$ : Cupriavidus metallidurans: evolution of a metal-resistant bacterium. Antonie Van Leeuwenhoek 2009, 96: I1 5-39.

25. Stanier RY, Palleroni NJ, Doudoroff M: The aerobic pseudomonads: a taxonomic study. J Gen Microbiol 1966, 43:I59-27I.

26. Kung VL, Ozer EA, Hauser AR: The accessory genome of Pseudomonas aeruginosa. Microbiol Mol Biol Rev 2010, 74:62I-4I.

27. Qiu X, Kulasekara BR, Lory S: Role of Horizontal Gene Transfer in the Evolution of Pseudomonas aeruginosa Virulence. Genome Dyn 2009, 6:126-39.

\section{FlOOOPrime \\ RECOMMENDED}

28. Klockgether J, Würdemann D, Reva O, Wiehlmann L, Tümmler B: Diversity of the abundant pKLCI02/PAGI-2 family of genomic islands in Pseudomonas aeruginosa. J Bacteriol 2007, I 89:2443-59.

29. Qiu X, Gurkar AU, Lory S: Interstrain transfer of the large pathogenicity island (PAPI-I) of Pseudomonas aeruginosa. Proc Natl Acad Sci USA 2006, 103:19830-5.

\section{FlOOOPrime
RECOMMENDED}

30. Minoia M, Gaillard M, Reinhard F, Stojanov M, Sentchilo V, van der Meer JR: Stochasticity and bistability in horizontal transfer control of a genomic island in Pseudomonas. Proc Natl Acad Sci USA 2008, 1 05:20792-7.

3I. Sentchilo V, Czechowska K, Pradervand N, Minoia M, Miyazaki R, van der Meer JR: Intracellular excision and reintegration dynamics of the ICEclc genomic island of Pseudomonas knackmussii sp. strain B I3. Mol Microbiol 2009, 72:1293-306.

\section{FlOOOPrime}

\section{RECOMMENDED}

32. Cady KC, Bondy-Denomy J, Heussler GE, Davidson AR, O'Toole GA: The CRISPR/Cas adaptive immune system of Pseudomonas aeruginosa mediates resistance to naturally occurring and engineered phages. J Bacteriol 20I2, I94:5728-38.

\section{FlOOOPrime \\ RECOMMENDED}

33. Bondy-Denomy J, Pawluk A, Maxwell KL, Davidson AR: Bacteriophage genes that inactivate the CRISPR/Cas bacterial immune system. Nature 2013, 493:429-32.

\section{FlOOOPrime \\ RECOMMENDED}

34. Rakhimova E, Wiehlmann L, Brauer AL, Sethi S, Murphy TF, Tümmler B: Pseudomonas aeruginosa population biology in chronic obstructive pulmonary disease. I Infect Dis 2009, 200:1928-35

35. Martínez-Solano L, Macia MD, Fajardo A, Oliver A, Martinez JL: Chronic Pseudomonas aeruginosa infection in chronic obstructive pulmonary disease. Clin Infect Dis 2008, 47:I526-33.

36. Ratjen F, Döring G: Cystic fibrosis. Lancet 2003, 36 I:68I-9.

37. Pezzulo AA, Tang $X X$, Hoegger MJ, Alaiwa MHA, Ramachandran S, Moninger TO, Karp PH, Wohlford-Lenane CL, Haagsman HP, van Eijk M, Bánfi B, Horswill AR, Stoltz DA, McCray PB, Welsh MJ, Zabner J: Reduced airway surface $\mathrm{pH}$ impairs bacterial killing in the porcine cystic fibrosis lung. Nature 2012, 487:109-13.

\section{FlOOOPrime}

\section{RECOMMENDED}

38. Cramer N, Wiehlmann L, Ciofu O, Tamm S, Høiby N, Tümmler B: Molecular epidemiology of chronic Pseudomonas aeruginosa airway infections in cystic fibrosis. PLOS ONE 2012, 7:e5073I. 
39. Kennemann L, Didelot X, Aebischer T, Kuhn S, Drescher B, Droege M, Reinhardt R, Correa P, Meyer TF, Josenhans C, Falush D, Suerbaum S: Helicobacter pylori genome evolution during human infection. Proc Natl Acad Sci USA 20I I, 108:5033-8.

40. Smith EE, Buckley DG, Wu Z, Saenphimmachak C, Hoffman LR, D'Argenio DA, Miller SI, Ramsey BW, Speert DP, Moskowitz SM, Burns JL, Kaul R, Olson MV: Genetic adaptation by Pseudomonas aeruginosa to the airways of cystic fibrosis patients. Proc Natl Acad Sci USA 2006, 103:8487-92.

\section{FlOOOPrime}

\section{RECOMMENDED}

4I. Jelsbak L, Johansen HK, Frost A, Thøgersen R, Thomsen LE, Ciofu O, Yang L, Haagensen JAJ, Høiby N, Molin S: Molecular epidemiology and dynamics of Pseudomonas aeruginosa populations in lungs of cystic fibrosis patients. Infect Immun 2007, 75:22I4-24.

42. Cramer N, Klockgether J, Wrasman K, Schmidt M, Davenport CF, Tümmler B: Microevolution of the major common Pseudomonas aeruginosa clones C and PAI4 in cystic fibrosis lungs. Environ Microbiol 20I I, 13:1690-704.

43. Döring G, Parameswaran IG, Murphy TF: Differential adaptation of microbial pathogens to airways of patients with cystic fibrosis and chronic obstructive pulmonary disease. FEMS Microbiol Rev 20II, 35:124-46.

44. Oliver A, Cantón R, Campo P, Baquero F, Blázquez J: High frequency of hypermutable Pseudomonas aeruginosa in cystic fibrosis lung infection. Science 2000, 288:|25|-4.

\section{FlOOOPrime}

\section{RECOMMENDED}

45. Mena A, Smith EE, Burns JL, Speert DP, Moskowitz SM, Perez JL, Oliver A: Genetic adaptation of Pseudomonas aeruginosa to the airways of cystic fibrosis patients is catalyzed by hypermutation. J Bacteriol 2008, 190:7910-7.

46. López-Causapé C, Rojo-Molinero E, Mulet X, Cabot G, Moyà B, Figuerola J, Togores B, Pérez JL, Oliver A: Clonal dissemination, emergence of mutator lineages and antibiotic resistance evolution in Pseudomonas aeruginosa cystic fibrosis chronic lung infection. PLOS ONE 20I3, 8:e7IO0I.

47. Bezuidt OK, Klockgether J, Elsen S, Attree I, Davenport CF, Tümmler B: Intraclonal genome diversity of Pseudomonas aeruginosa clones CHA and TB. BMC Genomics 20I3, 14:416.

48. Dacheux D, Goure J, Chabert J, Usson Y, Attree I: Pore-forming activity of type III system-secreted proteins leads to oncosis of Pseudomonas aeruginosa-infected macrophages. Mol Microbiol 200I, 40:76-85

49. Klockgether J, Miethke N, Kubesch P, Bohn Y, Brockhausen I, Cramer N, Eberl L, Greipel J, Herrmann C, Herrmann S, Horatzek S, Lingner $M$, Luciano L, Salunkhe P, Schomburg D, Wehsling $M$, Wiehlmann L, Davenport CF, Tümmler B: Intraclonal diversity of the Pseudomonas aeruginosa cystic fibrosis airway isolates TBCFI0839 and TBCFI21838: distinct signatures of transcriptome, proteome, metabolome, adherence and pathogenicity despite an almost identical genome sequence. Environ Microbiol 2013, 15:191-210.

50. Bohn YT, Brandes G, Rakhimova E, Horatzek S, Salunkhe P, Munder A, van Barneveld A, Jordan D, Bredenbruch F, Häussler S, Riedel K, Eberl L, Jensen PØ, Bjarnsholt T, Moser C, Hoiby N, Tümmler B, Wiehlmann L: Multiple roles of Pseudomonas aeruginosa TBCFI0839 PilYI in motility, transport and infection. Mol Microbiol 2009, 71:730-47.

51. Yang L, Jelsbak L, Marvig RL, Damkiær S, Workman CT, Rau MH, Hansen SK, Folkesson A, Johansen HK, Ciofu O, Høiby N, Sommer MOA, Molin S: Evolutionary dynamics of bacteria in a human host environment. Proc Natl Acad Sci USA 201I, 108:748|-6.

FlOOOPrime RECOMMENDED

52. Rau MH, Marvig RL, Ehrlich GD, Molin S, Jelsbak L: Deletion and acquisition of genomic content during early stage adaptation of Pseudomonas aeruginosa to a human host environment. Environ Microbiol 2012, 14:2200-II.

53. Folkesson A, Jelsbak L, Yang L, Johansen HK, Ciofu O, Høiby $N$, Molin S: Adaptation of Pseudomonas aeruginosa to the cystic fibrosis airway: an evolutionary perspective. Nat Rev Microbiol 2012, I0:84|-5|.

54. Marvig RL, Johansen HK, Molin S, Jelsbak L: Genome analysis of a transmissible lineage of pseudomonas aeruginosa reveals pathoadaptive mutations and distinct evolutionary paths of hypermutators. PLoS Genet 2013, 9:e I00374I.

\section{FlOOOPrime}

55. Salunkhe P, Smart CHM, Morgan JAW, Panagea S, Walshaw MJ, Hart CA, Geffers R, Tümmler B, Winstanley C: A cystic fibrosis epidemic strain of Pseudomonas aeruginosa displays enhanced virulence and antimicrobial resistance. J Bacteriol 2005, 187:4908-20.

56. Mowat E, Paterson S, Fothergill JL, Wright EA, Ledson MJ, Walshaw MJ, Brockhurst MA, Winstanley C: Pseudomonas aeruginosa population diversity and turnover in cystic fibrosis chronic infections. Am J Respir Crit Care Med 20I I, I83:1674-9.

57. Fothergill JL, Walshaw MJ, Winstanley C: Transmissible strains of Pseudomonas aeruginosa in cystic fibrosis lung infections. Eur Respir J 2012, 40:227-38.

58. Ashish A, Paterson S, Mowat E, Fothergill JL, Walshaw MJ, Winstanley C: Extensive diversification is a common feature of Pseudomonas aeruginosa populations during respiratory infections in cystic fibrosis. J Cyst Fibros 2013.

59. Aaron SD, Vandemheen KL, Ramotar K, Giesbrecht-Lewis T, Tullis E, Freitag A, Paterson N, Jackson M, Lougheed MD, Dowson C, Kumar V, Ferris W, Chan F, Doucette S, Fergusson D: Infection with transmissible strains of Pseudomonas aeruginosa and clinical outcomes in adults with cystic fibrosis. JAMA 20I0, 304:2। 145-53.

60. Workentine ML, Sibley CD, Glezerson B, Purighalla S, NorgaardGron JC, Parkins MD, Rabin HR, Surette MG: Phenotypic heterogeneity of Pseudomonas aeruginosa populations in a cystic fibrosis patient. PLOS ONE 2013, 8:e60225.

6I. Naughton S, Parker D, Seemann T, Thomas T, Turnbull L, Rose B, Bye P, Cordwell S, Whitchurch $C$, Manos J: Pseudomonas aeruginosa AES-I exhibits increased virulence gene expression during chronic infection of cystic fibrosis lung. PLOS ONE 20I I, 6:e24526.

62. Kidd TJ, Ritchie SR, Ramsay KA, Grimwood K, Bell SC, Rainey PB: Pseudomonas aeruginosa exhibits frequent recombination, but only a limited association between genotype and ecological setting. PLOS ONE 2012, 7:e44I99.

63. Kidd TJ, Ramsay KA, Hu H, Marks GB, Wainwright CE, Bye PT Elkins MR, Robinson PJ, Rose BR, Wilson JW, Grimwood K, Bell SC: Shared Pseudomonas aeruginosa genotypes are common in Australian cystic fibrosis centres. Eur Respir J 2013, 41:1091-100.

64. Scott NE, Hare NJ, White MY, Manos J, Cordwell SJ: Secretome of Transmissible Pseudomonas aeruginosa AES-IR Grown in a Cystic Fibrosis Lung-Like Environment. J Proteome Res 2013, | 2:5357-69.

65. Sonnleitner E, Gonzalez N, Sorger-Domenigg T, Heeb S, Richter AS, Backofen R, Williams P, Hüttenhofer A, Haas D, Bläsi U: The small RNA PhrS stimulates synthesis of the Pseudomonas aeruginosa quinolone signal. Mol Microbiol 20I I, 80:868-85.

\section{FlOOOPrime
RECOMMENDED}

66. Lapouge K, Perozzo R, Iwaszkiewicz J, Bertelli C, Zoete V, Michielin O, Scapozza L, Haas D: RNA pentaloop structures as effective targets of regulators belonging to the RsmA/CsrA protein family. RNA Biol 2013, 10:103I-4I.

\section{FlOOOPrime}

RECOMMENDED

67. Blanka A, Schulz S, Eckweiler D, Franke R, Bielecka A, Nicolai T, Casilag F, Düvel J, Abraham W, Kaever V, Häussler S: Identification of the alternative sigma factor SigX regulon and its 
implications for Pseudomonas aeruginosa pathogenicity. J Bacteriol 2013, 196:345-56.

\section{FlOOOPrime
RECOMMENDED}

68. Douzi B, Ball G, Cambillau C, Tegoni M, Voulhoux R: Deciphering the $\mathrm{Xcp}$ Pseudomonas aeruginosa type II secretion machinery through multiple interactions with substrates. $\mathrm{J} \mathrm{Biol} \mathrm{Chem}$ 20II, 286:40792-80I.

69. Tyson GH, Hauser AR: Phosphatidylinositol 4,5-bisphosphate is a novel coactivator of the Pseudomonas aeruginosa cytotoxin ExoU. Infect Immun 2013, 81:2873-8I.

70. Howell HA, Logan LK, Hauser AR: Type III secretion of ExoU is critical during early Pseudomonas aeruginosa pneumonia. MBio 2013, 4:e00032-I3

7I. Balczon R, Prasain N, Ochoa C, Prater J, Zhu B, Alexeyev M, Sayner S, Frank DW, Stevens T: Pseudomonas aeruginosa exotoxin $Y$ mediated tau hyperphosphorylation impairs microtubule assembly in pulmonary microvascular endothelial cells. PLoS ONE 2013, 8:e74343.

72. Anderson DM, Feix JB, Monroe AL, Peterson FC, Volkman BF, Haas AL, Frank DW: Identification of the major ubiquitinbinding domain of the Pseudomonas aeruginosa ExoU A2 phospholipase. J Biol Chem 2013, 288:2674I-52.

73. Russell AB, Hood RD, Bui NK, LeRoux M, Vollmer W, Mougous JD: Type VI secretion delivers bacteriolytic effectors to target cells. Nature 201 I, 475:343-7.

\section{FlOOPrime}

\section{RECOMMENDED}

74. Li M, Le Trong I, Carl MA, Larson ET, Chou S, de Leon JA, Dove SL, Stenkamp RE, Mougous JD: Structural basis for type VI secretion effector recognition by a cognate immunity protein. PLoS Pathog 2012, 8:el0026I3

\section{FIOOOPrime}

75. Sana TG, Hachani A, Bucior I, Soscia C, Garvis S, Termine E, Engel J, Filloux $A$, Bleves $S$ : The second type VI secretion system of Pseudomonas aeruginosa strain PAOI is regulated by quorum sensing and Fur and modulates internalization in epithelial cells. J Biol Chem 20I2, 287:27095-I05.

76. Hachani A, Lossi NS, Filloux A: A visual assay to monitor T6SSmediated bacterial competition. J Vis Exp 2013, e50103.

77. Russell $A B$, LeRoux M, Hathazi $K$, Agnello DM, Ishikawa $T$, Wiggins PA, Wai SN, Mougous JD: Diverse type VI secretion phospholipases are functionally plastic antibacterial effectors. Nature 2013, 496:508-12.

\section{FlOOOPrime} RECOMMENDED

78. Basler M, Ho BT, Mekalanos J]: Tit-for-tat: type VI secretion system counterattack during bacterial cell-cell interactions. Cell 2013, I52:884-94.

\section{FlOOOPrime} RECOMMENDED

79. Li L, Zhang W, Liu Q, Gao Y, Gao Y, Wang Y, Wang DZ, Li Z, Wang $T$ : Structural Insights on the Bacteriolytic and Selfprotection Mechanism of Muramidase Effector Tse3 in Pseudomonas aeruginosa. J Biol Chem 20I3, 288:30607-I3.

80. Silverman JM, Agnello DM, Zheng H, Andrews BT, Li M, Catalano CE, Gonen T, Mougous JD: Haemolysin coregulated protein is an exported receptor and chaperone of type VI secretion substrates. Mol Cell 2013, 51:584-93.

8I. Julou T, Mora T, Guillon L, Croquette V, Schalk IJ, Bensimon D, Desprat N: Cell-cell contacts confine public goods diffusion inside Pseudomonas aeruginosa clonal microcolonies. Proc Natl Acad Sci USA 2013, I I 0:12577-82.

82. Morales DK, Grahl N, Okegbe C, Dietrich LEP, Jacobs NJ, Hogan DA: Control of Candida albicans metabolism and biofilm formation by Pseudomonas aeruginosa phenazines. MBio 2013, 4:e00526-12

83. Cezairliyan B, Vinayavekhin N, Grenfell-Lee D, Yuen GJ, Saghatelian A, Ausubel FM: Identification of Pseudomonas aeruginosa phenazines that kill Caenorhabditis elegans. PLoS Pathog 20I3, 9: el003101.

84. Dietrich LEP, Okegbe C, Price-Whelan A, Sakhtah H, Hunter RC, Newman DK: Bacterial community morphogenesis is intimately linked to the intracellular redox state. J Bacteriol 2013 , | 95: | 37|-80.

85. Recinos DA, Sekedat MD, Hernandez A, Cohen TS, Sakhtah H, Prince AS, Price-Whelan A, Dietrich LEP: Redundant phenazine operons in Pseudomonas aeruginosa exhibit environmentdependent expression and differential roles in pathogenicity. Proc Natl Acad Sci USA 2012, 109:19420-5.

\section{FlOOOPrime}

RECOMMENDED

86. Kalia VC: Quorum sensing inhibitors: an overview. Biotechnol Adv 2013, 3 I:224-45.

87. O'Loughlin CT, Miller LC, Siryaporn A, Drescher K, Semmelhack MF, Bassler BL: A quorum-sensing inhibitor blocks Pseudomonas aeruginosa virulence and biofilm formation. Proc Natl Acad Sci USA 2013, I 10:17981-6.

88. Zhao K, Tseng BS, Beckerman B, Jin F, Gibiansky ML, Harrison JJ, Luijten E, Parsek MR, Wong GCL: Psl trails guide exploration and microcolony formation in Pseudomonas aeruginosa biofilms. Nature 20I3, 497:388-9I.

\section{FIOOOPYIme
RECOMMENDED}

89. Petrova OE, Sauer K: SagS contributes to the motile-sessile switch and acts in concert with BfiSR to enable Pseudomonas aeruginosa biofilm formation. J Bacteriol 20 I I, I 93:66 |4-28.

\section{FlOOOPrime
RECOMMENDED}

90. Liao J, Sauer K: The MerR-like transcriptional regulator BrIR contributes to Pseudomonas aeruginosa biofilm tolerance. Bacteriol 2012, 194:4823-36

91. Gupta K, Marques CNH, Petrova OE, Sauer K: Antimicrobial tolerance of Pseudomonas aeruginosa biofilms is activated during an early developmental stage and requires the twocomponent hybrid SagS. J Bacteriol 20I3, 195:4975-87.

92. Li Y, Heine S, Entian M, Sauer K, Frankenberg-Dinkel N: NOinduced biofilm dispersion in Pseudomonas aeruginosa is mediated by an MHYT domain-coupled phosphodiesterase. Bacteriol 2013, 195:3531-42

\section{FIOOOPrime
RECOMMENDED}

93. Chambers JR, Sauer K: The MerR-like regulator BrIR impairs Pseudomonas aeruginosa biofilm tolerance to colistin by repressing PhoPQ. J Bacteriol 2013, 195:4678-88.

94. Kong W, Chen L, Zhao J, Shen T, Surette MG, Shen L, Duan K: Hybrid sensor kinase PAI6II in Pseudomonas aeruginosa regulates transitions between acute and chronic infection through direct interaction with RetS. Mol Microbiol 2013, 88:784-97.

95. Korgaonkar A, Trivedi U, Rumbaugh KP, Whiteley M: Community surveillance enhances Pseudomonas aeruginosa virulence during polymicrobial infection. Proc Natl Acad Sci USA 2013, I I 0: 1059-64

96. Mougous JD, Cuff ME, Raunser S, Shen A, Zhou M, Gifford CA, Goodman AL, Joachimiak G, Ordoñez CL, Lory S, Walz T, Joachimiak A, Mekalanos J]: A virulence locus of Pseudomonas aeruginosa encodes a protein secretion apparatus. Science 2006, 3 I 2:1526-30.

\section{FlOOOPrime}

\section{RECOMMENDED}

97. Leiman PG, Basler M, Ramagopal UA, Bonanno JB, Sauder JM, Pukatzki S, Burley SK, Almo SC, Mekalanos J]: Type VI secretion 
apparatus and phage tail-associated protein complexes share a common evolutionary origin. Proc Natl Acad Sci USA 2009, 106:4I54-9.

\section{FlOOOPrime}

\section{RECOMMENDED}

98. Hood RD, Singh P, Hsu F, Güvener T, Carl MA, Trinidad RRS, Silverman JM, Ohlson BB, Hicks KG, Plemel RL, Li M, Schwarz S, Wang WY, Merz AJ, Goodlett DR, Mougous JD: A type VI secretion system of Pseudomonas aeruginosa targets a toxin to bacteria. Cell Host Microbe 2010, 7:25-37.

\section{FlOOOPrime}

99. Lesic B, Starkey M, He J, Hazan R, Rahme LG: Quorum sensing differentially regulates Pseudomonas aeruginosa type $V I$ secretion locus I and homologous loci II and III, which are required for pathogenesis. Microbiology (Reading, Engl) 2009, I55:2845-55. 